\title{
THE TRIS(BIURETATO)COBALTATE(III) ION
} The Crystal Structure of Potassium tris(biuretato)cobaltate(III) hydrate

\author{
BY
}

\section{P. J. M. W. L. BIRKER, J. M. M. SMITS, J. J. BOUR and P. T. BEURSKENS}

(Department of Inorganic Chemistry, University of Nijmegen, Toernooiveld, Nijmegen, The Netherlands)

\begin{abstract}
The structure of the octahedral $\mathbf{N}_{6}$-coordinated potassium tris(biuretato)cobaltate(III) hydrate, $\mathrm{K}_{3} \mathrm{Co}(\mathrm{HN}-\mathrm{CO}-\mathrm{NH}-\mathrm{CO}-\mathrm{NH})_{3} \cdot \mathrm{xH}_{2} \mathrm{O}(\mathrm{x}=6.38$ ) was determined by $\mathrm{X}$-ray analysis. The crystals are triclinic, space group $\mathbf{P} \overline{1}$, with unit cell dimensions $a=9.296, b=11.168, c=11.631 \AA, \alpha=93.76^{\circ}, \beta=112.71^{\circ}$, $\gamma=74.57^{\circ}$ and two formula units per cell. 3275 non-zero reflections were measured with an automatic diffractometer. The structure was refined by full matrix least-squares methods to a conventional $R$-value of 0.05 . The cobalt is in nearly regular octahedral coordination with an average $\mathrm{Co}-\mathrm{N}$ distance of $1.916 \AA$. The slightly puckered biuretato ligands are somewhat bent out of the plane formed by four coordinating nitrogen atoms and the cobalt atom.
\end{abstract}

\section{Introduction}

In previous communications from this laboratory ${ }^{1,2}$, the synthesis and identification of copper, nickel and cobalt complexes with biuret were reported. It was shown that the deprotonated biuret ligand strongly stabilizes planar coordination and that the planar $\mathbf{N}_{4}$-coordinated metal(II) bis(biuretato) complexes could be oxidized to isostructural complex ions in which the central metal atom is formally tervalent:

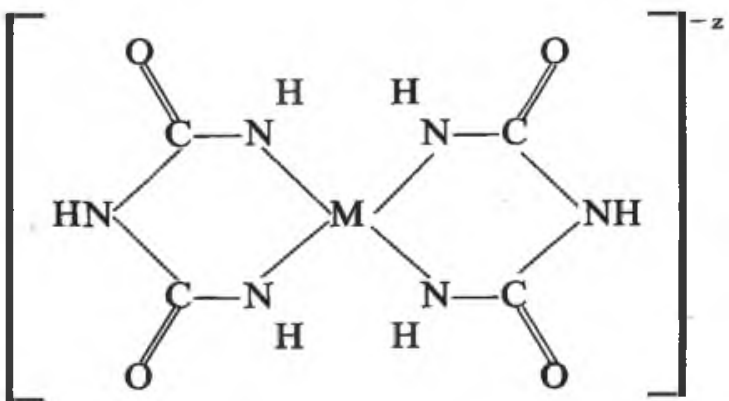

$$
\mathrm{M}=\mathrm{Cu}, \mathrm{Co}, \mathrm{Ni}, \quad \mathrm{z}=1,2
$$

1 J.J. Bour, P. J.M.W.L. Birker and J.J. Steggerda, Inorg. Chem. 10, 1202 (1971).

${ }^{2}$ P. J.M.W. L. Birker, J.J. Bour and J. J. Steggerda, Inorg. Chem. 12, 1254 (1973). 
The structure of the bis(3-n-propylbiuretato)cobaltate(III) ion was determined by $\mathbf{X}$-ray crystallographic methods and found to be planar ixcept for the propyl groups ${ }^{3}$. The planar cobalt(III) complex ions have a stable spin triplet ground state ${ }^{2}$. They appeared to have very little affinity for further ligands, presumably due to the high electronic charge induced on the central metal atom by the deprotonated biuret ligand which is a very strong base. Very labile bis(amino)bis(biuretato)cobaltate(III) adducts could be isolated with primary amines ${ }^{2,4}$.

There are some reports in the literature about another cobalt(III) biuret complex. Kato 5 postulated an $\mathrm{N}_{6}$-coordinated tris(biuretato)cobaltate(III) species to be present in the red solution obtained by the reaction of labile cobalt amino complexes with biuret in alkaline solution or by aerial oxidation of a slurry of cobalt hydroxide and biuret. Such a solution is diamagnetic and the UV spectrum is very similar to that of $\mathrm{Co}\left(\mathrm{NH}_{3}\right)_{6} \mathrm{Cl}_{3}$. So an octahedral complex was assumed to be present, and from a spectrophotometric titration the cobalt: biuret ratio appeared to be about $1: 3$. The stable spin triplet bis(biuretato)cobaltate(III) complexes were prepared ${ }^{2}$ from red solutions obtained in this way. In addition there are some vague reports about the formation and the infra red spectrum of a cobalt(III) biuret complex ${ }^{6}$, but as no detailed preparations and analyses are given and the infra red spectrum of poor quality, all these reports are inconclusive.

In view of the lability of the bis(amino)bis(biuretato)cobaltate(III) adducts, the existence of a tris(biuretato)cobaltate(III) species was questionable. Coordination of another extremely strong base to the slightly electrophilic central cobalt atom seemed improbable. For that reason investigations were carried out to establish the structure of the red complex definitely.

\section{Results and discussion}

When an aqueous slurry of one mole of cobalt(II) acetate, three moles of biuret and more than nine moles of potassium hydroxide was aerated for 24 hours, a red solution of the compound in question was obtained.

3 J. J. Bour, P. T. Beurskens and J. J. Steggerda, Chem. Comm. 1972, 221.

4 J. J. Bour and J. J. Steggerda, Proc. Third Symp. Coord. Chem., Debrecen, Hungary 1970, 274.

5 M. Kato, Z. für Anorg. und Allg. Chemie 300, 84 (1959).

6 P. K. Pal, R. M. Sanyal and B. K. Banerjee, Technology (India) 3, 217 (1966).

R. M. Sanyal and P. K. Pal, Technology (India) 1, 62 (1964).

R. M. Sanyal, A. K. Chakravorty and S. K. Ghosh, Technology (India) 5, 185 (1968). 
After filtration of such a solution so much alcohol was added that a precipitate began to form. After a few days standing red crystals separated. The compound is diamagnetic (Gouy method) and its ultra viole spectrum (measured on a Unicam SP700C) in alkaline aqueous solution is typical for an octahedrally coordinated cobalt(III) complex: $v_{1}=20.6 \mathrm{kK}(\varepsilon=220)\left({ }^{1} \mathrm{~A}_{1 \mathrm{~g}} \rightarrow{ }^{1} \mathrm{~T}_{1 \mathrm{~g}}\right) ; v_{2}=28.0 \mathrm{kK}(\varepsilon=175)\left({ }^{1} \mathrm{~A}_{1 \mathrm{~g}} \rightarrow\right.$ $\left.{ }^{1} \mathrm{~T}_{2 \mathrm{~g}}\right) ; v_{3}=12.8 \mathrm{kK}(\varepsilon=1.5)\left({ }^{1} \mathrm{~A}_{1 \mathrm{~g}} \rightarrow{ }^{3} \mathrm{~T}_{1 \mathrm{~g}}\right) ; 10 \mathrm{D}_{\mathrm{q}}=24.5 \mathrm{kK} ; \mathrm{B}=$ $460 \mathrm{~K} ; \mathrm{cf} . \mathrm{Co}\left(\mathrm{NH}_{3}\right)_{6} \mathrm{Cl}_{3}{ }^{7}: v_{1}=21.2 \mathrm{kK}(\varepsilon=56) ; v_{2}=29.5 \mathrm{kK}(\varepsilon=46)$; $v_{3}=13.0 \mathrm{kK}(\varepsilon=0.2) ; 10 \mathrm{D}_{\mathrm{q}}=22.9 \mathrm{kK} ; \mathrm{B}=615 \mathrm{~K}$.

The analyses of the red products from different preparations were neither reproducible, nor did they provide an unambiguous indication

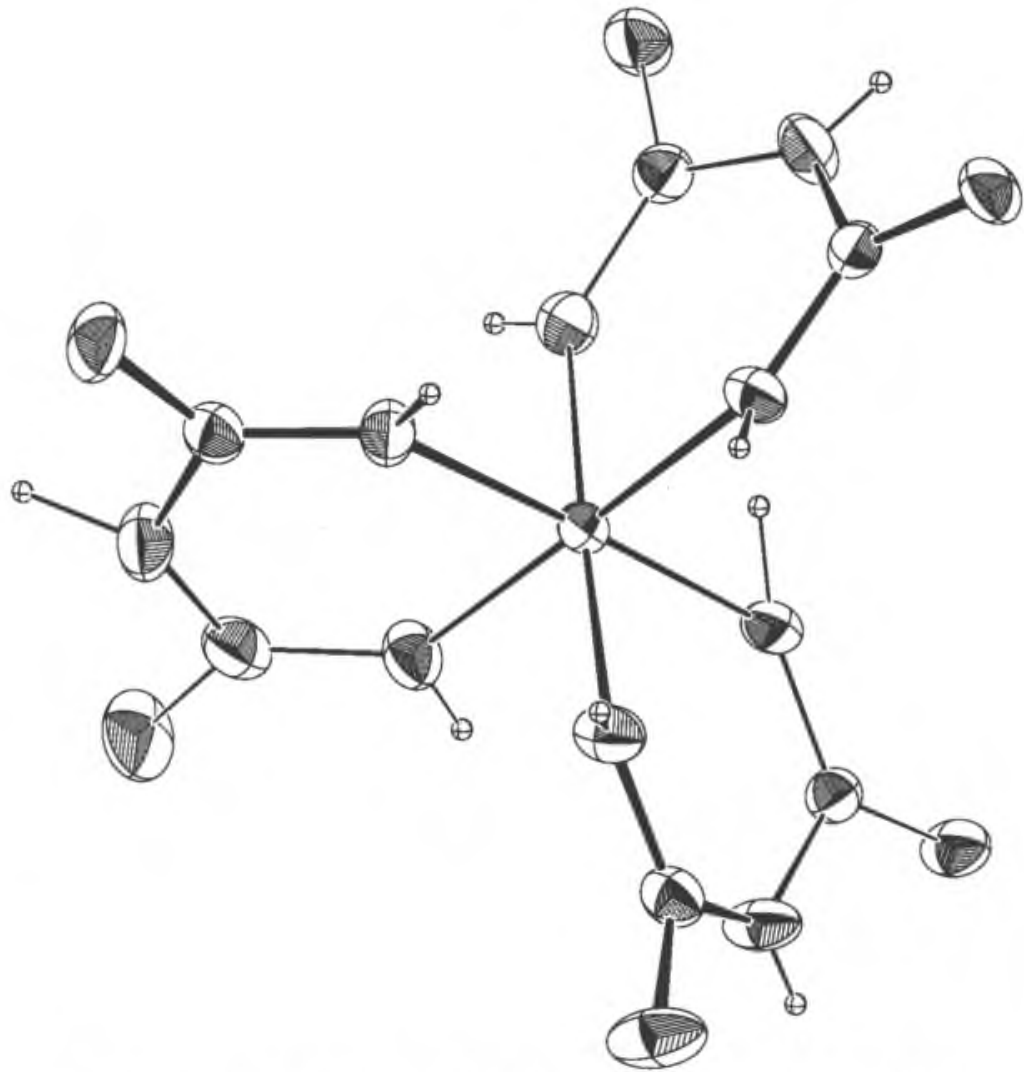

Fig. 1. Projection of the anion along the $a^{*}$ axis on the $b c$ plane, showing the anisotropic vibration ellipsoids. The hydrogen positions are very inaccurate (esd $=0.2 \AA$ ).

7 A. B.P. Lever, Inorganic Electronic Spectroscopy. Elseviers Publishing Company, Amsterdam, London, New York 1968, page 302-305. 
about the composition of the compound. The atomic ratios for four samples were found to be $\mathrm{C}_{6.0} \mathrm{H}_{19.8} \mathrm{~N}_{9.7} ; \mathrm{C}_{6.0} \mathrm{H}_{21.8} \mathrm{~N}_{9.6} ; \mathrm{C}_{6.0} \mathrm{H}_{24.6} \mathrm{~N}_{10.0}$; $\mathrm{Co}_{1.17} \mathrm{C}_{6.0} \mathrm{H}_{21.4} \mathrm{~N}_{8.8}$. Assuming the cobalt: biuret ratio to be $1: 3$ the composition of the compound should be $\mathrm{K}_{3} \mathrm{CoC}_{6} \mathrm{H}_{9} \mathrm{~N}_{9} \mathrm{O}_{6} \cdot \mathrm{xH}_{2} \mathrm{O}$. From the analytical data $x$ is calculated to be $6.0 \pm 0.5$. An $X$-ray structural investigation was carried out (see below) and the product was shown indeed to contain the tris(biuretato)cobaltate(III) ion: $\mathrm{Co}(\mathrm{HN}-\mathrm{CO}-\mathrm{NH}-\mathrm{CO}-\mathrm{NH})_{3}{ }^{3-}$. The complex ion is shown in Figure 1. Three biuret ligands are coordinated through nitrogen to a cobalt atom, forming a trivalent complex anion. The cobalt atom is in nearly regular octahedral coordination. When the structures of the bis(biuretato)cobaltate(III) ion $^{3}$ and the tris(biuretato)cobaltate(III) ion are compared with one another, it is clear that the ligands are not unaffected by the coordination of a third biuretato ligand. In the tris(biuretato) compound the ligands are less planar than in the bis(biuretato) complex. The whole ligand is slightly puckered and it is bent out of the plane formed by four coordinating nitrogen atoms and the cobalt atom (see Table III and Fig. 2). Relative to the triangles formed by the nitrogen atoms in a ligand, ligands 1 and 2 have a chair and ligand 3

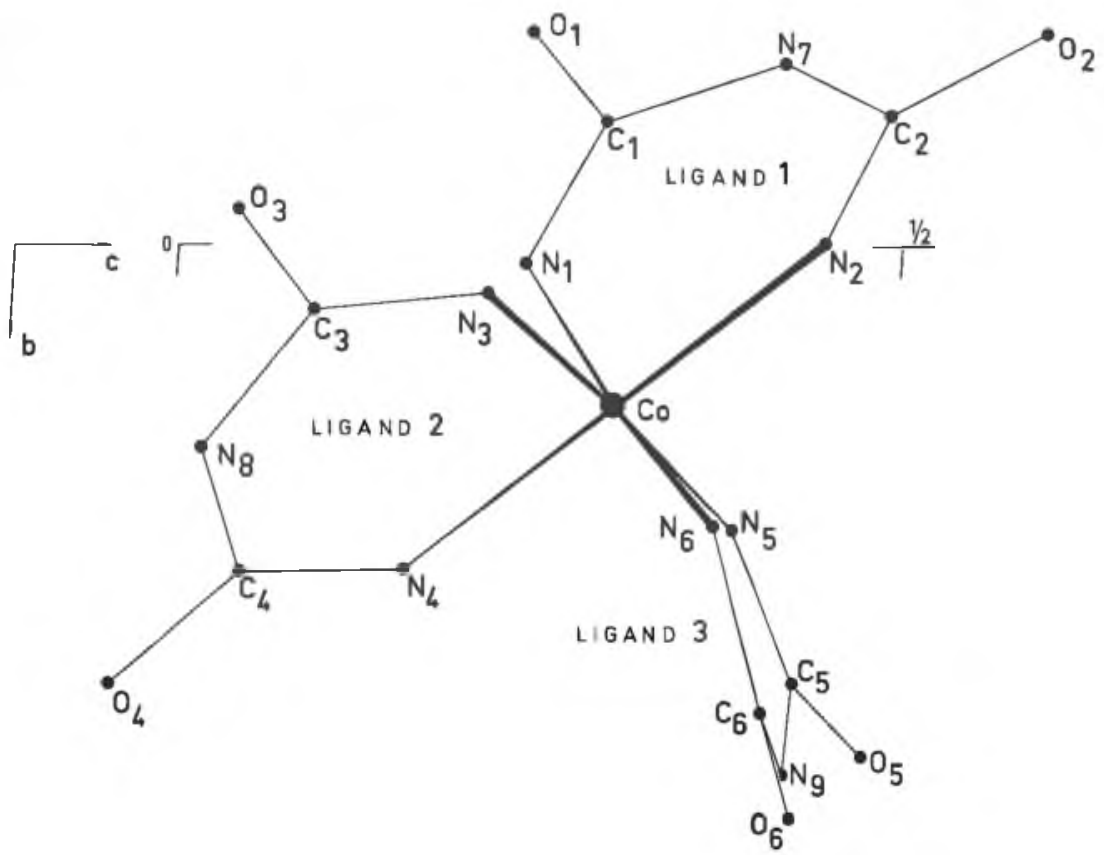

Fig. 2. Projection of the anion along the a axis on the $b c$ plane, with atomic numbering. 
has a boat configuration (ligand 3 is shown in nearly vertical position in Fig. 2). The average cobalt-nitrogen distance is longer in the tris(biuretato) complex: in $\mathrm{Co}\left(\mathrm{HN}-\mathrm{CO}-\mathrm{N}\left(\mathrm{C}_{3} \mathrm{H}_{7}\right)-\mathrm{CO}-\mathrm{NH}\right)_{2}^{-}$it is $1.88 \AA$, in $\mathrm{Co}(\mathrm{HN}-\mathrm{CO}-\mathrm{NH}-\mathrm{CO}-\mathrm{NH})_{3}^{3-}$ it is $1.92 \AA$. This could be the result of a greater repulsion between the less positive cobalt atom and the negatively charged ligands in the tris(biuretato) complex, wherein three strongly electron donating ligands are present.

The crystal structure analysis showed the presence of seven $\mathrm{H}_{2} \mathrm{O}$ sites, one of which was occupied to the extent of only $38 \%$. So the composition of the crystal was $\mathrm{K}_{3} \mathrm{Co}(\mathrm{HN}-\mathrm{CO}-\mathrm{NH}-\mathrm{CO}-\mathrm{NH})_{3}$. $6.38 \mathrm{H}_{2} \mathrm{O}$. As distinction between the occupancy of these sites by $\mathrm{H}_{2} \mathrm{O}$ or $\mathrm{NH}_{3}$ is difficult, the variations in analytical data are possibly caused by the presence of some $\mathrm{NH}_{3}$ (from partial hydrolysis of biuret) instead of $\mathrm{H}_{2} \mathrm{O}$ in the crystal lattice.

\section{Crystal structure determination}

\section{Crystal data}

Potassium tris(biuretato)cobaltate(III) hydrate, $\mathrm{K}_{3} \mathrm{Co}(\mathrm{III})\left(\mathrm{C}_{2} \mathrm{H}_{3} \mathrm{~N}_{3} \mathrm{O}_{2}\right)_{3}$. $\mathrm{xH}_{2}$ O. With $\mathrm{x}=6.38, \mathrm{~F} . \mathrm{W} .=594$. 4. The crystals are triclinic, space group $\mathrm{P} \overline{1}$, with $a=9.296 \pm 0.004 \AA, b=11.168 \pm 0.006 \AA, c=11.631$ 工 $0.006 \AA, \alpha=93.76 \pm 0.03^{\circ}, \beta=112.71 \pm 0.03^{\circ}, \gamma=74.57 \pm 0.03^{\circ}$, $\mathrm{V}=1073 \AA^{3}$. The crystals are elongated along $a$. The calculated density $\left(1.84{\mathrm{~g} . \mathrm{cm}^{-3}}^{-3}\right.$, for $\mathrm{Z}=2$, agrees with the observed density $(1.80 \pm 0.05$ g.cm ${ }^{-3}$ ), but does not permit of a determination of the hydration number.

A crystal of approximate dimensions of $0.69-0.14-0.09 \mathrm{~mm}^{3}$, was mounted with the $a$-axis along the $\phi$-axis of a Nonius CAD3 diffractometer. Intensity data were measured with $\mathrm{Zr}$-filtered Mo-radiation using the moving-crystal stationary-counter method with a scan speed of $10 \% / \mathrm{min}$. Reference reflections were measured to check the measuring performance. Of the 4239 independent reflections theoretically attainable within the limit $\theta=26^{\circ}, 3275$ non-zero reflections were used for the structure determination. Lorentz and polarisation corrections were performed in the usual way. No absorption corrections were made (linear absorption coefficient $\mu=14.8 \mathrm{~cm}^{-1}$; maximum effect upon the intensities : $2 \%$ ).

\section{Structure determination}

The structure was solved using Patterson and Fourier methods. Positional and anisotropic vibrational parameters were refined by full- 
matrix least-squares methods. The function that was minimized was ${ }^{\top} \mathrm{w}\left(\left|\mathrm{F}_{\mathrm{o}}\right|-\left|\mathrm{F}_{\mathrm{c}}\right|\right)^{2}$, with $\mathrm{w}=\left[\sigma^{2}\left(\mathrm{~F}_{\mathrm{o}}\right)+\left(0.05\left|\mathrm{~F}_{\mathrm{o}}\right|\right)^{2}\right]^{-1}, \sigma\left(\mathrm{F}_{\mathrm{o}}\right)$ being calculated from counting statistics. Scattering factors used were those for $\mathrm{Co}^{3+}, \mathrm{K}^{+}, \mathrm{C}, \mathrm{N}, \mathrm{O}$ and $\mathrm{H}$, with corrections for $\Delta \mathrm{f}$, using data from the International Tables ${ }^{8}$.

\section{Table I}

Positional parameters of the non-hydrogen atoms.

(The given esd's are averages for the following atoms.)

\begin{tabular}{|c|c|c|c|c|c|c|c|}
\hline Atom & $\mathbf{x}$ & $\mathrm{y}$ & z & Atom & $\mathbf{x}$ & y & 2 \\
\hline esd & .00007 & .00005 & .00005 & esd & .0004 & .0003 & .0003 \\
\hline Co & .16038 & .11595 & .30834 & $\begin{array}{l}O(1) \\
O(2)\end{array}$ & $\begin{array}{r}-.0908 \\
.3288\end{array}$ & $\begin{array}{l}-.1519 \\
-.1499\end{array}$ & $\begin{array}{l}.2353 \\
.5914\end{array}$ \\
\hline esd & .0005 & .0004 & .0004 & $O(3)$ & .3374 & -.0261 & .0394 \\
\hline C(1) & .0094 & -.0873 & .2896 & $O(4)$ & -.0743 & .3124 & -.0286 \\
\hline $\mathrm{C}(2)$ & 2509 & -.0920 & .4871 & $O(5)$ & -.0784 & .3623 & .4952 \\
\hline$C(3)$ & .2580 & .0456 & .0964 & $O(6)$ & .3594 & .4069 & .4505 \\
\hline C(4) & .0252 & .2323 & .0571 & & & & \\
\hline C(5) & .0196 & .3116 & .4437 & esd & .0008 & .0006 & .0006 \\
\hline$C(6)$ & .2688 & .3325 & .4232 & $\begin{array}{l}\mathrm{O}(7) \\
\mathrm{O}(8)\end{array}$ & $\begin{array}{l}.3737 \\
.3816\end{array}$ & $\begin{array}{l}.7281 \\
.6616\end{array}$ & $\begin{array}{l}.0767 \\
.3271\end{array}$ \\
\hline esd & .00045 & .00035 & .00035 & O(9) & .4901 & .6929 & .8793 \\
\hline $\mathbf{N}(1)$ & .0156 & .0123 & .2412 & $\mathrm{O}(10)$ & -.1618 & .5407 & .0583 \\
\hline $\mathrm{N}(2)$ & .2896 & -.0020 & .4462 & $Q(11)$ & -.3205 & .5737 & .2277 \\
\hline $\mathrm{N}(3)$ & .2880 & .0341 & 2152 & $\mathrm{O}(12)$ & .3221 & .1774 & .6814 \\
\hline $\mathbf{N}(4)$ & .0297 & .2305 & .1698 & & & & \\
\hline $\mathrm{N}(5)$ & .0285 & .2018 & .3954 & esd & .0034 & .0026 & .0027 \\
\hline$N(6)$ & .3018 & .2215 & .3814 & $\mathrm{O}(13)^{*}$ & .2863 & .3773 & .1609 \\
\hline$N(7)$ & .1152 & -.1289 & .4108 & & & & \\
\hline $\mathrm{N}(8)$ & .1364 & .1434 & .0247 & esd & .00014 & .00011 & .00011 \\
\hline \multirow[t]{3}{*}{$\mathrm{N}(9)$} & .1240 & .3772 & .4389 & $\mathbf{K}(1)$ & .40465 & .59478 & .63881 \\
\hline & & & & $K(2)$ & .38440 & .94603 & .82023 \\
\hline & & & & $\mathbf{K}(3)$ & .09745 & .60255 & .25925 \\
\hline
\end{tabular}

* The occupancy-factor of $O(13)$ was refined to $0.38(16)$.

Including the oxygen atoms of six water molecules, and without hydrogen atoms the conventional $\mathbf{R}$-value reduced to 0.06 . At this stage reflections with $\sin \theta / \lambda<0.30$ were used to locate hydrogen atoms from a difference fourier synthesis, to refine the positions of the biurethydrogen atoms (with fixed temperature parameters), and to refine

8 International Tables for X-ray Crystallography III (1962), Kynoch Press, Birmingham, 1962. 
the position and the occupancy factor of $\mathrm{O}(13)$ (one $2 \mathrm{e} / \AA^{3}$ peak in the difference map, assumedly a nonstoechiometric water site). The posi tions of the water-hydrogen atoms could not be determined.

Table II

Selected bond distances and angles.

\begin{tabular}{|l|c|c|l|l|}
\hline \multicolumn{1}{|c|}{ type } & $\begin{array}{c}\text { average } \\
\text { dist }(\AA) \\
\text { or angles }\end{array}$ & (min - max) & esd & (n) \\
\hline $\mathrm{Co}-\mathrm{N}(1)$ & 1.916 & $(1.908-1.924)$ & 0.004 & $(4)$ \\
$\mathrm{N}(1)-\mathrm{C}(1)$ & 1.308 & $(1.298-1.324)$ & 0.006 & $(6)$ \\
$\mathrm{C}(1)-\mathrm{N}(2)$ & 1.383 & $(1.378-1.394)$ & 0.007 & $(6)$ \\
$\mathrm{C}(1)-\mathrm{O}(1)$ & 1.271 & $(1.261-1.278)$ & 0.006 & $(6)$ \\
$\mathrm{N}-\mathrm{H}$ & 0.87 & $(0.66-1.26)$ & 0.18 & $(9)$ \\
$\mathrm{N}-\mathrm{Co}-\mathrm{N}$ & $90.0^{\circ}$ & $(88.7-91.6)$ & 0.2 & $(1.2)$ \\
$\mathrm{Co}-\mathrm{N}(1)-\mathrm{C}(1)$ & $129.6^{\circ}$ & $(128.5-131.5)$ & 0.3 & $(6)$ \\
$\mathrm{N}(1)-\mathrm{C}(1)-\mathrm{N}(2)$ & $119.3^{\circ}$ & $(118.1-120.0)$ & 0.4 & $(6)$ \\
$\mathrm{C}(1)-\mathrm{N}(2)-\mathrm{C}(2)$ & $128.9^{\circ}$ & $(128.5-129.2)$ & 0.4 & $(3)$ \\
$\mathrm{N}(1)-\mathrm{C}(1)-\mathrm{O}(1)$ & $125.0^{\circ}$ & $(124.6-125.5)$ & 0.4 & $(6)$ \\
$\mathrm{N}(2)-\mathrm{C}(2)-\mathrm{O}(1)$ & $115.7^{\circ}$ & $(114.0-117.4)$ & 0.4 & $(6)$ \\
& & & & \\
\hline
\end{tabular}

Potassium coordination (including $\mathbf{O}(13)$.

\begin{tabular}{|l|l|l|l|l|}
\hline $\mathbf{K}(1)-\mathrm{O}$ & 2.858 & $(2.744-3.00)$ & $*$ & $(71 / 3)$ \\
$\mathrm{K}(2)-\mathrm{O}$ & 2.819 & $(2.712-2.941)$ & & $(6)$ \\
$\mathbf{K}(3)-\mathrm{O}$ & 2.867 & $(2.698-3.09)$ & & $(61 / 3)$ \\
\hline
\end{tabular}

* esd's vary in the range $0.003-0.009$, except for $\mathrm{O}(13)$.

$\mathrm{O}(13)$-coordination (occupancy factor $\approx 1 / 3$ )

\begin{tabular}{|l|l|l|l|l|}
\hline O(13)-K & 3.04 & $(3.00-3.09)$ & 0.03 & (2) \\
O(13)-O & 2.35 & $(2.23-2.48)$ & 0.03 & (2) \\
O(13)-others & & 3.13 & & \\
\hline
\end{tabular}

Hydrogen bonding (excluding O(13). 1 = ligand, $w=$ water.

\begin{tabular}{|l|l|l|l|l|}
\hline & & & \\
N...O(1) & 2.951 & $(2.891-3.040)$ & 0.005 & $(3)$ \\
O(1)...O(w) & $2^{7} 43$ & $(2.715-2.759)$ & 0.007 & $(5)$ \\
O(w)...O(w) & 2.393 & $(2.838-3.022)$ & 0.010 & $(5)$ \\
O...others & & 3.17 & & \\
\hline
\end{tabular}


Structure factor calculation including the nine hydrogen atoms and $\bigcirc(13)$ gave $\mathbf{R}=0.053$, and further refinement with fixed hydrogen atoms educed the R-value to 0.050 for 3275 observed reflections. Final parameter shifts were all less than 0.3 esd. The final difference fourier map showed highest maxima of $0.4 \mathrm{e} / \AA^{3}$ near $\mathrm{O}(13)$ and near the cobalt atom.

Positional parameters of the non-hydrogen atoms are given in Table I, selected geometrical data are given in Table II*.

\section{Table III}

Non-panarity of the ligands.

The tabulated data for each ligand refer to the plane through the three nitrogen atoms. $d_{o}$ is the distance of Co to this plane; $d_{1}$ and $d_{2}$ are the distances from the oxygen atoms to this plane. $\alpha_{1}$ and $\alpha$ are the dihedral angles between this plane and the coordination planes around the carbon atoms (for instance the $\mathrm{N}(6) \mathrm{N}(9) \mathrm{O}(6)$ plane).

\begin{tabular}{|c|c|c|c|c|c|}
\hline & $\mathrm{d}_{\mathrm{o}}$ & $\mathrm{d}_{1}$ & $\mathrm{~d}_{2}$ & $\alpha_{1}$ & $\alpha_{2}$ \\
\hline ligand 1 & 0.28 & -0.35 & 0.11 & 20.33 & 3.25 \\
ligand 2 & 0.17 & -0.08 & 0.14 & 4.20 & 0.80 \\
ligand 3 & 0.52 & 0.45 & 0.19 & 13.45 & 5.75 \\
\hline
\end{tabular}

\section{Description of the structure}

The geometry of the anion is discussed above. Bond distances and angles are in the expected range (see refs. 3 and 9, and references therein).

The coordinations of the $\mathrm{K}^{+}$ions are rather irregular. Considering, for instance, the coordination-polyhedron of $\mathrm{K}(2)$ as a distorted trigonal prism, we find edges in the range 2.76 $4.35 \AA$. The coordinations of $\mathrm{K}(1)$ and $K(3)$ are also irregular and depend on whether or not the $O(13)$ site is occupied.

The hydrogen-bonding scheme is not established definitely. The anion is linked by $\mathrm{NH}-\mathrm{O}$ bonds to symmetry-related anions, and by $\mathrm{O}-\mathrm{HO}$ bonds to water molecules. There are twelve water-hydrogen atoms (excluding $\mathrm{O}(13)$ ) of which nine are involved in less-than-3.0 $\AA$ hydrogen bonds. One $3.02 \AA$ contact is a possible fifth hydrogen bond

* The remaining structural parameters and structure factor tables, are available on request.

9 M. Nardelli, G. Fava and G. Giraldi, Acta Cryst. 16, 343 (1963). 
involving $\mathrm{O}(7)$. Several more-than-3.17 $\AA$ contacts may lead to weak hydrogen bonds, with unfavourable bond angles. Several hydrogenbonding schemes may then be postulated and we assume therefore tha. the structure is disordered. There may then be large variations in the positions of the water molecules, which is in agreement with the large temperature factor parameters. (E.g. the rms displacement of $\mathrm{O}(9)$ is $0.4 \AA$.)

The observed electron density at the $O(13)$ site is now easily explained by assuming that a water molecule can go in only when its hydrogen can interact with the surrounding water molecules. The short distance $\mathrm{O}(13)-\mathrm{O}(9)=2.2 \AA$ is not prohibitive, as it is an average over all possible $\mathrm{O}(9)$-positions.

The crystal structure is a complicated three-dimensional network of electrostatic, hydrogen bonding, and van der Waals interactions, which we will not try to describe.

\section{Acknowledgement}

The investigations were supported in part by the Netherlands Foundation for Chemical Research (SON) with financial aid from the Netherlands Organization for the Advancement of Pure Research. We wish t thank Professor J.J. Steggerda for his continuous interest in the work, Dr. J. H. Noordik for the X-ray measurements and Mr. J. Diersmann for performing the analyses. 